\title{
Novel in vitro inhibitory functions of potato tuber proteinaceous inhibitors
}

\author{
Matthias Fischer • Markus Kuckenberg • \\ Robin Kastilan · Jost Muth $\cdot$ Christiane Gebhardt
}

Received: 2 July 2014 / Accepted: 23 August 2014 / Published online: 27 September 2014

(C) The Author(s) 2014. This article is published with open access at Springerlink.com

\begin{abstract}
Plant protease inhibitors are a structurally highly diverse and ubiquitous class of small proteins, which play various roles in plant development and defense against pests and pathogens. Particular isoforms inhibit in vitro proteases and other enzymes that are not their natural substrates, for example proteases that have roles in human diseases. Mature potato tubers are a rich source of several protease inhibitor families. Different cultivars have different inhibitor profiles. With the objective to explore the functional diversity of the natural diversity of potato protease inhibitors, we randomly selected and sequenced 9,600 cDNA clones originated from mature tubers of ten potato cultivars. Among these, 120 unique inhibitor cDNA clones were identified by homology searches. Eighty-eight inhibitors represented novel sequence variants of known plant protease inhibitor families. Most frequent were Kunitztype inhibitors (KTI), potato protease inhibitors I and II (PIN), pectin methylesterase inhibitors, metallocarboxypeptidase inhibitors and defensins. Twenty-three inhibitors were functionally characterized after heterologous expression in the yeast Pichia pastoris. The purified recombinant
\end{abstract}

Communicated by S. Hohmann.

Electronic supplementary material The online version of this article (doi:10.1007/s00438-014-0906-5) contains supplementary material, which is available to authorized users.

M. Fischer · M. Kuckenberg · C. Gebhardt $(\bowtie)$

Department Plant Breeding and Genetics, Max-Planck

Institute for Plant Breeding Research, Carl von LinnéWeg 10,

50829 Cologne, Germany

e-mail: gebhardt@mpipz.mpg.de

R. Kastilan · J. Muth

Fraunhofer Institute for Molecular Biology and Applied Ecology,

Forckenbeckstraße 6, 52074 Aachen, Germany proteins were tested for inhibitory activity on trypsin, eleven pharmacological relevant proteases and the non-proteolytic enzyme 5-lipoxygenase. Members of the KTI and PIN families inhibited pig pancreas elastase, $\beta$-Secretase, Cathepsin K, HIV-1 protease and potato 5-lipoxygenase. Our results demonstrate in vitro inhibitory diversity of small potato tuber proteins commonly known as protease inhibitors, which might have biotechnological or medical applications.

Keywords Potato (Solanum tuberosum L.) · Tuber · Enzyme inhibitor $\cdot$ Protease inhibitor $\cdot$ Heterologous expression $\cdot$ Pichia pastoris

\section{Introduction}

Protease inhibitors (PIs) are ubiquitous, small proteins which are particularly abundant in plant reproductive and storage organs such as seeds and tubers (Ryan 1990). They account for $1-10 \%$ of the total protein in storage tissues. In higher plants, several PI families have been characterized for their molecular structure and biochemical function. The structural basis of the interaction between proteases and their inhibitors is under continuous investigation (Bateman and James 2011; Mosolov and Valueva 2005). PIs are involved in many physiological processes via control of protease activity. The best characterized example is their role in wound-induced defense responses of plants against herbivores and pathogens (Hartl et al. 2011; Jorgensen et al. 2006). They are also considered as storage proteins (Ryan 1990).

Potato tuber protein consists mainly of patatin, the major storage protein, and numerous low molecular weight PIs which can be classified in at least ten different families 
(De Leo et al. 2002; Rawlings et al. 2008). Most abundant are inhibitors of serine proteases from families known as Kunitz-type inhibitors (KTI), potato protease inhibitors I and II (PIN I, PIN II) and Bowman-Birk inhibitors (BBIs). KTIs are one of the best characterized inhibitors. These vacuolar proteins are abundant in potato tubers and represent a highly diverse group of proteins (Heibges et al. 2003a). Most KTIs are encoded at a complex locus on potato chromosome III, which is linked to a quantitative trait locus (QTL) for resistance to the oomycete Phytophthora infestans (Heibges et al. 2003a; Odeny et al. 2010). Most KTIs consist of a single polypeptide chain of approximately $24 \mathrm{kDa}$ with two disulfide bridges and a single reactive site. Depending on the cultivar studied, potato KTIs were classified in three to six structural subgroups (A, B, C, D, K and M) (Bauw et al. 2006; Heibges et al. 2003a; Ishikawa et al. 1994; Oliva et al. 2010). The tremendous structural variability among KTIs suggested functional diversity (Heibges et al. 2003b). Previous studies revealed that KTIs have distinct target specificities in vitro and some have dual or broad specificity. Inhibitors of subgroup KTI-A reduced the activity of serine or aspartic proteases such as trypsin or cathepsin D (Heibges et al. 2003b; Ishikawa et al. 1994). Members of subgroup KTI-B inhibited trypsin, chymotrypsin or elastase and members of subgroup KTI-C inhibited not only subtilisin and cysteine proteases, but also other enzymes like invertase (Glaczinski et al. 2002; Heibges et al. 2003b). Similar to KTIs, the PIN I and PIN II families display high structural and functional diversity, particularly in the Solanaceae, and are organized as gene clusters mainly on potato chromosome IX and III, respectively. Plant PINs have been characterized at the biochemical and molecular level. PIN I protein was first isolated from potato tubers (Balls and Ryan 1963). More recent studies demonstrated PIN I expression in leaves, stems, flowers and tuber sprouts, which is regulated by both environmental and developmental signals (Johnson and Ryan 1990; Turra et al. 2009; Valueva et al. 2003). Proteins homologous to PIN I are found in several plant species such as barley or maize, while PIN II's seem to be restricted to the Solanaceae (Mosolov and Valueva 2005). PIN proteins are suggested to function in plant interactions with herbivores and microbes. Digestive enzymes in the guts of herbivores were inhibited by plant PINs, restricting the absorption of essential amino acids and consequently interfering with herbivore growth and development (Chen 2008). In vitro assays confirmed inhibitory effects of plant PINs on the digestive serine proteases trypsin, chymotrypsin or subtilisin (Hartl et al. 2010; Mosolov and Valueva 2005; Turra et al. 2009).

The detrimental effect observed on herbivores and pests led to the development of inhibitor-transgenic plants (Chen 2008; Dunse et al. 2010). However, due to the adaptation of herbivores by maintaining diverse digestive enzymes and over-expressing inhibitor insensitive enzymes, and last but not least due to the rejection of transgenic crops by the public, transgenic approaches have not been widely adopted in commercial food crops (Jongsma and Bolter 1997; Zhu et al. 2005). Beyond plant biotechnology, plant PIs became attractive targets in pharmacology and drug development. Inhibitors of KTI and BBI families, purified from different leguminous seeds, were shown to block the activity of several proteases and enzymes involved in human diseases (reviewed in (Oliva and Sampaio 2009)). Plant KTIs inhibited proteins acting in the blood clotting cascade or in fibrinolysis such as factor XIIa, factor Xa, thrombin, plasmin, plasma kallikrein or tissue plasminogen activator (Cruz-Silva et al. 2004; Oliva and Sampaio 2008; Oliva et al. 2000). Elastase and cathepsin G involved in inflammatory processes in humans were shown to be inhibited by KTIs isolated from Bauhinia seeds (Neuhof et al. 2003; Oliveira et al. 2010). Several studies revealed antitumor activity of BBI and KTI inhibitors (Oliva and Sampaio 2009; Oliva et al. 2010). Trypsin inhibitors from Peltophorum dubium (PDTI) and soybean induced cell death of human leukemic Jurkat cell lines by activation of caspases 3 and 8. Inhibitors from seeds of the Chinese black soybean Glycine max suppressed cell proliferation of MCF-7 breast cancer cells and HepG2 hepatoma cells. Peptides derived from Bauhinia rufa trypsin Inhibitor (BrTI) inhibited the adhesion of tumor cells to extracellular matrix glycoproteins (Nakahata et al. 2006). In summary, KTI effects were investigated in inflammation, thrombosis, AIDS (auto immune deficiency syndrome), parasitic diseases and antifungal activity (Oliva et al. 2010).

In this paper, we tap at the tremendous structural diversity of proteinaceous inhibitors found in tubers of different potato genotypes and their potential inhibitory functions. Novel variants of KTI, PIN I, PIN II and other types of proteinaceous inhibitors were isolated as full length cDNAs from tubers of ten different potato varieties. A subset was expressed as recombinant fusion proteins in the yeast Pichia pastoris and examined for inhibitory properties on serine, cysteine and aspartic proteases involved in human diseases including Alzheimer disease, AIDS and osteoporosis, as well as on the potato enzyme lipoxygenase.

\section{Materials and methods}

Plant material

Field grown tubers from nine potato varieties (Lady Claire, Omega, Eurobeta, Verdi, Elfe, Marabel, Allians, Solara, Melba) and one breeding clone (Breeding clone 18) were provided by EUROPLANT Pflanzenzucht GmbH (Ebstorf, 
Germany). Tubers were peeled, washed and snap frozen in liquid nitrogen. Tuber tissue was homogenized by Mixer Mill MM 200 (Retsch, Haan, Germany) and stored at $-80{ }^{\circ} \mathrm{C}$ until use.

\section{cDNA libraries}

Total RNA was isolated from $5 \mathrm{~g}$ powdered, frozen tuber tissue using the PureLink ${ }^{\circledR}$ Plant-RNA reagent (Invitrogen ${ }^{\mathrm{TM}}$, Carlsbad, USA) according to the manufacturer's guidelines. Poly $\mathrm{A}^{+}$RNA was prepared from total RNA using the Poly(A)Purist ${ }^{\mathrm{TM}}$ MAG purification kit (Ambion ${ }^{\circledR}$, Austin, USA) following the suppliers instructions. Ten cDNA libraries were constructed from Poly $\mathrm{A}^{+}$RNA of the ten genotypes. cDNA synthesis and transformation of Electromax $^{\mathrm{TM}} \mathrm{DH} 10 \mathrm{~B}^{\mathrm{TM}} \mathrm{T} 1$ Phage resistant $E$. coli cells were performed using to the CloneMiner ${ }^{\mathrm{TM}}$ II cDNA Library construction kit (Invitrogen ${ }^{\mathrm{TM}}$, Carlsbad, USA) and the supplier's protocol. 960 cDNA clones per library were randomly selected (9,600 clones total) and stored in 96-well microtiter plates.

\section{cDNA sequence analysis}

Plasmid insertions were sequenced from the $5^{\prime}$ end using a primer (5'GTAAAACGACGGCCAGT3') matching to the M13-forward (-20) priming site of the pDONR ${ }^{\mathrm{TM}} 222 \mathrm{vec}-$ tor which was used for cDNA library construction. Custom DNA Sanger-sequencing was performed at the Max-Planck Genome Center [Cologne, Germany (http://mpgc.mpipz. mpg.de/home/)]. Inhibitor sequences were identified by BLAST comparisons to the NCBI nucleotide collection (NR/NT). cDNA clones coding for various inhibitors of proteases and other enzymes were selected and sequenced from the $3^{\prime}$ end using a primer $\left(5^{\prime}\right.$ AACAGCTATGAC

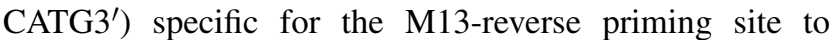
identify full length cDNA clones. Recombinant E. coli clones harboring inhibitor sequences were propagated in LB-media ( $1 \%$ Tryptone, $0.5 \%$ yeast extract, $1 \% \mathrm{NaCl}$, $\mathrm{pH} 7$ ) containing $50 \mu \mathrm{g} / \mathrm{ml}$ kanamycin. Plasmid DNA was isolated using the Plasmid Mini Kit (QIAGEN ${ }^{\circledR}$, Hilden, Germany) according to the manufacturer's guidelines and stored at $-20{ }^{\circ} \mathrm{C}$.

Heterologous expression of cDNAs encoding protease inhibitors

cDNAs encoding mature protease inhibitors were cloned into the multiple cloning sites (MCS) of the expression vector pPICZ $\alpha \mathrm{A}$ (Invitrogen ${ }^{\mathrm{TM}}$, Carlsbad, USA) without their putative signal sequences. Putative signal sequences were identified using SignalP 4.0 software (http://www. cbs.dtu.dk/services/SignalP/). Translation termination sequences were omitted in fusing inhibitor sequences with the c-myc epitope and His-tag of the pPICZ $\alpha \mathrm{A}$ vector. Expression of fusion proteins was controlled by the methanol-inducible AOX1 promoter. The native $\alpha$-factor secretion signal sequence from Saccharomyces cerevisiae allowed secretion of the fusion protein into the medium. For expression cloning, inhibitor sequences were amplified by PCR using $1 \mathrm{ng}$ plasmid DNA as template and the primers specified in Table 1. PCR conditions were: $95^{\circ} \mathrm{C}$ for $5 \mathrm{~min}$, followed by 20 cycles of $95^{\circ} \mathrm{C}$ for $1 \mathrm{~min}, 60^{\circ} \mathrm{C}$ for $1 \mathrm{~min}$ and $72{ }^{\circ} \mathrm{C}$ for $1.5 \mathrm{~min}$ with a final extension step at $72{ }^{\circ} \mathrm{C}$ for 5 min. Cloning of PCR products into the pPICZ $\alpha \mathrm{A}$ vector and transformation of Pichia pastoris cells (strain GS115) was accomplished with the EasySelect ${ }^{\mathrm{TM}}$ Pichia Expression Kit (Invitrogen ${ }^{\mathrm{TM}}$, Carlsbad, USA) according to the suppliers protocol. Nucleotide sequences were verified by direct sequencing.

\section{Expression of recombinant proteins}

Recombinant $P$. pastoris-strains expressing a specific inhibitor were pre-cultured by inoculating $100 \mathrm{ml}$ BMGY medium ( $1 \%$ yeast extract, $2 \%$ peptone, $100 \mathrm{mM}$ potassium phosphate $\mathrm{pH} 6,1.34 \%$ yeast nitrogen base, $0.0004 \%$ biotin, $1 \%$ glycerol) with a single colony. Cultures were incubated with continuous shaking at $28{ }^{\circ} \mathrm{C}$ for $24 \mathrm{~h}$. Cells were harvested by centrifugation at $2,000 \times g$ for $10 \mathrm{~min}$ and re-suspended to an $\mathrm{OD}_{600}=1$ in $500 \mathrm{ml}$ BMMY medium ( $1 \%$ yeast extract, $2 \%$ peptone, $100 \mathrm{mM}$ potassium phosphate $\mathrm{pH} 6,1.34 \%$ yeast nitrogen base, $0.0004 \%$ biotin, $0.5 \% \mathrm{MeOH}$ ) to induce expression. P. pastoris cells were incubated for $72 \mathrm{~h}$ at $28{ }^{\circ} \mathrm{C}$ with continuous shaking. Every $24 \mathrm{~h} 100 \%$ Methanol was added to a final concentration of $0.5 \%$ to maintain induction. Cells were harvested by centrifugation for $10 \mathrm{~min}$ and $3,000 \times \mathrm{g}$. The supernatants were transferred to a new tube and subsequently used for protein purification.

Purification of heterologous expressed inhibitors

Solid ammonium sulfate was added to the supernatant of the Pichia pastoris cell culture to a final concentration of $40 \%$ and stirred for $30 \mathrm{~min}$ at room temperature (RT). After centrifugation at $10,000 \times g$ for $15 \mathrm{~min}$ at $4^{\circ}$, the pellet was dissolved in $5 \mathrm{ml}$ binding buffer $(0.02 \mathrm{M}$ $\mathrm{NaH}_{2} \mathrm{PO}_{4}, 1 \mathrm{M} \mathrm{NaCl}, 0.04 \mathrm{M}$ imidazole, $5 \%$ glycerol, $\mathrm{pH}$ 7.5). The protein solution was filtered through a syringe-attached $0.45 \mu \mathrm{m}$ filter and loaded onto a $5 \mathrm{ml}$ Protino $^{\circledR}$ Ni-NTA column (Macherey-Nagel, Düren, Germany) attached to an Äkta Prime Plus (GE Healthcare, Little Chalfont, UK) chromatographic system. The column was washed with $150 \mathrm{ml}$ binding buffer to remove unbound proteins. The His-tagged fusion protein 
Table 1 Primer sequences for expression cloning of 23 potato protease inhibitors in pPICZ $\alpha \mathrm{A}$

\begin{tabular}{|c|c|c|c|}
\hline Type & Inhibitor & Forward primer $\left(5^{\prime}-3^{\prime}\right)^{\mathrm{a}}$ & Reverse primer $\left(5^{\prime}-3^{\prime}\right)^{\mathrm{a}}$ \\
\hline \multirow[t]{5}{*}{ KTI-A } & PI0875 & AAAGAATTCATGGAATCTCCTGTACCTAAGCC & AAAGCGGCCGCGACTTCCTGGAATAAGACATCAAGA \\
\hline & PI4063 & AAAGAATTCATGGATACTACTCCATGTACTCCAGT & AAAGCGGCCGCGACTTCCTGGAAATAGACATCAAGA \\
\hline & PI6033 & AAAGAATTCATGGAATCTCCTGTACCTAAGCC & AAAGCGGCCGCGACTTCCTGGAATAAGACGTCAA \\
\hline & PI9070 & AAAGAATTCATGGAATCTCCTGTACCTAAGCC & AAAGCGGCCGCGACTTCCTGGAATAAGACATCAAGA \\
\hline & PI8311 & AAAGAATTCATGCTACCCAGTGCTAAGTCTGT & AAAGCGGCCGCGTCTTCGACTTTCTCAAATTCGA \\
\hline \multirow[t]{10}{*}{ KTI-B } & PI2112 & AAAGAATTCATGCCAGTACTTGACGTAACTGG & AAAGCGGCCGCCTGGACTTGCTTGAAGGAGAC \\
\hline & PI2568 & AAAGAATTCATGCCAGTACTTGACGTAACTGG & AAAGCGGCCGCCTGGACTTGCTTGAAGGAGAC \\
\hline & PI4435 & $\begin{array}{l}\text { AAAGAATTCATGCTACCTAGTGATGCTACTCCAG- } \\
\text { TACTT }\end{array}$ & AAAGCGGCCGCCTGGACTTGCATGAAGGAGAC \\
\hline & PI4587 & $\begin{array}{l}\text { AAAGAATTCATGCTACCTAGTGATGCTACTCCAG- } \\
\text { TACTT }\end{array}$ & AAAGCGGCCGCCTGGACTTGCTTGAAGGAGAC \\
\hline & PI5887 & AAAGAATTCATGCCAGTACTTGACGTAACTGG & AAAGCGGCCGCCTGGACTTGCTTGAAGGAGAC \\
\hline & PI5918 & AAAGAATTCATGCCAGTACTTGACGTAACTGG & AAAGCGGCCGCCTGGACTTGCTTGAAGGAGAC \\
\hline & PI6362 & $\begin{array}{l}\text { AAAGAATTCATGCTACCTAGTGATGCTACTCCAG } \\
\text { TACTT }\end{array}$ & AAAGCGGCCGCCTGGACTTGCTTGAAGGAGAC \\
\hline & PI8234 & AAAGAATTCATGCCAGTACTTGACGTAACTGG & AAAGCGGCCGCCTGGACTTGCTTGAAGGAGAC \\
\hline & PI8383 & AAAGAATTCATGCCAGTACTTGACGTAACTGG & AAAGCGGCCGCCTGGACTTGCTTGAAGGAGAC \\
\hline & PI9142 & $\begin{array}{l}\text { AAAGAATTCATGCTACCTAGTGATGCTACTCCAG } \\
\text { TACTT }\end{array}$ & AAAGCGGCCGCCTGGACTTGCTTGAAGGAGAC \\
\hline \multirow[t]{3}{*}{ KTI-C } & PI1410 & AAAGAATTCATGCTTGTACTCCCTGAAGTTTATG & AAAGCGGCCGCCGCCTTGATGAACACAAATG \\
\hline & PI4202 & AAAGAATTCATGCTTGTACTCCCTGAAGTTTATGACC & AAAGCGGCCGCCGCCTTGATGAACACAAATG \\
\hline & PI5446 & AAACACGTGCGAAAAGAAAGTGATGGACTAGAAG & AAAGCGGCCGCACCAACCACAGGAATTTGTACA \\
\hline \multirow[t]{2}{*}{ PIN I } & PI0234 & AAAGAATTCATGCGAAAAGAATGTGATGG & AAAGCGGCCGCACCAACCACAGGCATTGATAC \\
\hline & PI6013 & AAAGAATTCAGAGATTTGATCAGTGATGGCAT & AAAGCGGCCGCACCCATACTGGGAGGAATTTG \\
\hline \multirow[t]{2}{*}{ PIN II } & PI4434 & AAAGAATTCATGAAGGCTTGCACTTTAGAATG & AAAGCGGCCGCCATTGCAGGGTACATATTTGCC \\
\hline & PI6669 & AAAGAATTCATGAAGGCTTGCACTTTAGAATG & AAAGCGGCCGCCATTGCAGGGTACATATTTGCC \\
\hline PMEI & PI7531 & AAAGAATTCATGGCGGGTAACGCC & AAAGCGGCCGCATGATTTGCAGCATATTGGTT \\
\hline
\end{tabular}

${ }^{a}$ Underlined sequences are the restriction enzyme recognition sites used for cloning in pPICZ $\alpha$ A. GAATTC is recognized by EcoRI, CACGTG by $P m l I$ and GCGGCCGC by NotI

was eluted with $10 \mathrm{ml} 0.02 \mathrm{M} \mathrm{NaH}_{2} \mathrm{PO}_{4}, 1 \mathrm{M} \mathrm{NaCl}$, $0.25 \mathrm{M}$ imidazole, $5 \%$ glycerol, $\mathrm{pH}$ 7.5. Fractions containing the fusion protein were combined and the elution buffer was replaced with $0.01 \mathrm{M}$ Tris/ $\mathrm{HCl} \mathrm{pH} 7.5,5 \%$ glycerol using PD-10 desalting columns (GE Healthcare, Little Chalfont, UK) according to the manufacturer's guidelines. Eluted fusion protein was concentrated tenfold by ultrafiltration using Amicon ${ }^{\circledR}$ Ultra centrifugal filters (Millipore, Billerica, MS, USA). Protein concentration was estimated using Qubit $^{\circledR}$ Protein Assay (Invitrogen ${ }^{\mathrm{TM}}$, Carlsbad, USA) and BSA (bovine serum albumin) as standard. Proteins were snap frozen in liquid nitrogen and stored at $-80{ }^{\circ} \mathrm{C}$. Purification of fusion proteins was checked on SDS-PAGE using Anykd ${ }^{\mathrm{TM}}$ mini-protean ${ }^{\circledR} \mathrm{TGX}^{\mathrm{TM}}$ precast polyacrylamide gels (BioRad, Hercules, California, USA) according to the manufactures guidelines. Western blot analysis was performed using $10 \mathrm{ng}$ of purified protein and anti-c-myc antibody (Sigma Aldrich, St. Louis, MO, USA) following the protocol supplied with the antibody.
Enzyme inhibition assays

All inhibition assays were performed with purified recombinant inhibitor protein on commercially available enzymes using colorimetric assays. Enzymes were pre-incubated without inhibitor protein (control) and with single and double amounts of inhibitor protein as specified below. After pre-incubation, the enzymatic reactions were started by adding the substrate. Absorbance was recorded in a microplate reader (Synergy 4, BioTek, Winooski, VT, USA) and used to calculate the residual enzyme activity. Enzyme inhibition was expressed as percentage of the enzyme activity in the controls $(100 \%)$. In a first round of experiments, three to five inhibitors were pooled in different molar ratios of inhibitor and enzyme and tested for enzyme inhibition. In case inhibitory activity of a pool on the tested enzyme was detected, the inhibitors composing the pool were retested individually and values for the half maximal inhibitory concentration $\left(\mathrm{IC}_{50}\right)$ were calculated. IC50 values of active inhibitors were determined in triplicate by plotting 
percent initial activity against inhibitor concentrations from 0 to $8 \mu \mathrm{M}$ in independent experiments.

Trypsin: Trypsin (EC 3.4.21.4) was purchased from Sigma Aldrich (St. Louis, USA). The trypsin inhibition assay was performed according to (Heibges et al. 2003b) with minor modifications using azocasein as substrate. Trypsin stock solution $(5 \mathrm{mg} / \mathrm{ml})$ was prepared in a buffer containing $50 \mathrm{mM}$ Tris/ $\mathrm{HCl} \mathrm{pH} 7.5$ and $20 \mathrm{mM} \mathrm{CaCl}_{2}$. $5 \mu \mathrm{g}$ trypsin $(0.21 \mu \mathrm{M})$ was pre-incubated for $10 \mathrm{~min}$ at RT either without (control), or with 0.5 and $1 \mu \mathrm{M}$ purified inhibitor in $40 \mu \mathrm{l} 100 \mathrm{mM}$ Tris/ $\mathrm{HCl} \mathrm{pH}$ 7.5, $40 \mathrm{mM} \mathrm{CaCl}_{2}$. After adding $40 \mu \mathrm{l} 2 \%$ azocasein, the reactions were mixed by pipetting and incubated for $1 \mathrm{~h}$ at RT. Reactions were stopped by adding $80 \mu 112 \%$ TCA and incubation for $30 \mathrm{~min}$ at RT. Precipitate was removed by centrifugation and $100 \mu \mathrm{l}$ supernatant was transferred to a 96-well plate. $50 \mu \mathrm{l} 4 \mathrm{~N} \mathrm{NaOH}$ were added and the absorbance at $440 \mathrm{~nm}$ was measured.

Elastase: Porcine pancreas elastase (PPE, EC 3.4.21.36) was supplied as part of the EnzChek ${ }^{\circledR}$ Elastase Assay Kit (Invitrogen $^{\mathrm{TM}}$, Carlsbad, USA). Human leukocyte elastase (HLE, EC 3.4.21.37) was purchased from Sigma Aldrich (St. Louis, USA). HLE was reconstituted with $\mathrm{dH}_{2} \mathrm{O}$ to 1U/ $\mu \mathrm{l}$. PPE and HLE were diluted to $0.2 \mathrm{U} / \mathrm{ml}$ in $100 \mu \mathrm{l}$ assay buffer $(100 \mathrm{mM}$ Tris/ $\mathrm{HCl} \mathrm{pH} 8,0.2 \mathrm{mM}$ sodium azide) included in the EnzChek ${ }^{\circledR}$ Elastase Assay Kit, and incubated for $10 \mathrm{~min}$ at RT with either none (control), 200 or $400 \mathrm{nM}$ inhibitor protein. Elastase activity was determined according to the assay kit manufacturers' guidelines including elastase inhibitor control reactions. Fluorescence intensity of inhibitor samples was corrected for background fluorescence determined from samples without enzyme.

Dipeptidylpeptidase 4 (DPP4): Screening for DPP4 (EC 3.4.14.5) inhibitors was performed using the DPP4 Drug Discovery Kit $\left(\right.$ Enzo $^{\circledR}$ Life Sciences, Farmingdale, New York, USA) according to the manufacturer's guidelines. DPP4 activity was detected using the chromogenic (H-GlyPro-pNA) substrate supplied with the kit. DPP4 was preincubated for $10 \mathrm{~min}$ at $37{ }^{\circ} \mathrm{C}$ with either none (control), 100 or $200 \mathrm{nM}$ inhibitor protein. The assay was started by adding the substrate and the absorption at $405 \mathrm{~nm}$ was continuously read. A $405 \mathrm{~nm}$ values were plotted versus time until 15 min after addition of the substrate and a regression line was obtained. The slope was used to calculate DPP4 activity.

Factor IXa: Factor IXa (EC 3.4.21.22) was purchased from $\mathrm{Abcam}^{\circledR}$ (Cambridge, UK) and was diluted to $90 \mathrm{ng} / \mu \mathrm{l}$ in assay buffer $(50 \mathrm{mM}$ Tris/ $\mathrm{HCl} \mathrm{pH} 7.4,100 \mathrm{mM} \mathrm{NaCl}$, $5 \mathrm{mM} \mathrm{CaCl}^{2}, 40 \%$ ethylene glycol). $20 \mu \mathrm{l}$ of diluted enzyme solution was pre-incubated for $15 \mathrm{~min}$ at $37{ }^{\circ} \mathrm{C}$ with $200 \mu \mathrm{l}$ assay buffer containing none (control), 50 or $100 \mathrm{nM}$ protease inhibitor in a 96-well plate. The enzymatic reaction was initiated by adding $25 \mu \mathrm{l}$ of $10 \mathrm{mM}$ substrate solution
(Pefachrome ${ }^{\circledR}$ FIXa, Pentapharm, Basel, Switzerland) and increase in absorbance at $405 \mathrm{~nm}$ was recorded for $15 \mathrm{~min}$ at $37^{\circ} \mathrm{C}$. A linear regression was fitted to the linear proportion of the absorbance curve and the slope was calculated. The background slope determined from samples without enzymes was subtracted from enzyme and inhibitor samples.

Factor Xa: Factor Xa (EC 3.4.21.6) was purchased from Merck KGaA (Darmstadt, Germany) and was diluted to $5 \mathrm{ng} / \mu \mathrm{l}$ in assay buffer $(50 \mathrm{mM}$ Tris/ $\mathrm{HCl} \mathrm{pH} \mathrm{7.4,} 300 \mathrm{mM}$ $\mathrm{NaCl}, 200 \mu \mathrm{g} / \mathrm{ml} \mathrm{BSA}$ ). $10 \mu \mathrm{l}$ of diluted enzyme solution was incubated for $10 \mathrm{~min}$ at $37{ }^{\circ} \mathrm{C}$ in $80 \mu \mathrm{l}$ assay buffer including either none (control), 10 or $20 \mathrm{nM}$ inhibitor in a 96-well plate. $10 \mu \mathrm{l}$ of $4 \mathrm{mM}$ substrate solution (Pefachrome ${ }^{\circledR}$ FXa, Pentapharm, Basel, Switzerland) was then added and the increase in absorbance at $405 \mathrm{~nm}$ for 5 min at $37{ }^{\circ} \mathrm{C}$ was recorded. A linear regression was fitted to the linear proportion of the absorbance curve and the slope was calculated. The background slope determined from samples without enzyme was subtracted from control and inhibitor samples.

Thrombin: Thrombin from human plasma (EC 3.4.21.5) was purchased from Sigma Aldrich (St. Louis, USA). Thrombin enzyme solution was diluted in assay buffer (10 mM HEPES pH 7.5, $150 \mathrm{mM} \mathrm{NaCl}, 200 \mu \mathrm{g} / \mathrm{ml}$ BSA) to $7.5 \mathrm{ng} / \mu \mathrm{l}$. $10 \mu \mathrm{l}$ diluted enzyme solution was incubated for $10 \mathrm{~min}$ at $37{ }^{\circ} \mathrm{C}$ either without (control) or with 20 and $40 \mathrm{nM}$ purified inhibitor in $80 \mu \mathrm{l}$ assay buffer in a 96-well plate. After adding $20 \mu \mathrm{l}$ substrate solution $(0.5 \mathrm{mg} /$ $\mathrm{ml} \quad \mathrm{N}$-Benzoyl-L-phenylalanyl-L-valyl-L-arginine-4-nitroanilide. Merck KGaA, Darmstadt, Germany) release of $\rho$-nitroanilide $(\rho \mathrm{NA})$ was monitored by the increase in absorbance at $405 \mathrm{~nm}$ for $5 \mathrm{~min}$ at $37{ }^{\circ} \mathrm{C}$. Background absorption was determined from reaction mixtures without enzyme. A linear regression was fitted to the increase in absorbance and the enzyme activity was calculated from the slope. The slope of the background was subtracted from the slope of control measurements and the inhibitor samples.

$\beta$-Secretase (BACE-1): Screening for BACE (EC 3.4.23.46) inhibitors was performed using the BACE Inhibitor Screening assay kit (Cayman Chemical Company, Ann Arbor, MI, USA) according to the manufacturer's instructions. BACE was pre-incubated for $15 \mathrm{~min}$ at $4{ }^{\circ} \mathrm{C}$ with either none (control), 100 or $200 \mathrm{nM}$ inhibitor protein.

HIV1-Protease: Screening for HIV-1 protease (EC 3.4.23.16) inhibitors was performed using the Sensolyte ${ }^{\circledR}$ 490 HIV1 Protease Assay Kit (Ana Spec, Fremont, CA, USA) according to the manufacturer's guidelines. HIV-1 protease was purchased from Ana Spec (Fremont, CA, USA) and was diluted to $10 \mathrm{ng} / \mu \mathrm{l}(125 \mathrm{nM})$ with assay buffer complemented with Dithiothreitol (DTT) supplied with the kit. HIV-1 protease was pre-incubated for $15 \mathrm{~min}$ at room temperature with either none (control), 100 or $200 \mathrm{nM}$ inhibitor protein. 
Human Calpain-1: Screening for human calpain-1 (EC 3.4.22.52) inhibitors was performed using the Sensolyte ${ }^{\circledR}$ AMC Calpain Activity Assay (Ana Spec, Fremont, CA, USA) according to the manufacturer's protocol. Human calpain-1 (supplied with the kit) was pre-incubated for 5 min at $37^{\circ} \mathrm{C}$ with none (control), 100 or $200 \mathrm{nM}$ inhibitor protein.

Caspase-1: Screening for human Caspase-1 (EC 3.4.22.36) inhibitors was performed using the Caspase- 1 Drug Discovery Kit $\left(\right.$ Enzo $^{\circledR}$ Life Sciences, Farmingdale, New York, USA) according to the manufacturer's guidelines. Caspase-1 activity was detected using the chromogenic (AC-YVDA-pNA) substrate supplied with the kit. Caspase-1 was pre-incubated for $10 \mathrm{~min}$ at $30{ }^{\circ} \mathrm{C}$ with either none (control), 100 or $200 \mathrm{nM}$ inhibitor protein. The assay was started by adding the substrate and the absorption at $405 \mathrm{~nm}$ was continuously read for $30 \mathrm{~min}$. A $405 \mathrm{~nm}$ values were plotted versus time until $15 \mathrm{~min}$ after addition of the substrate and a regression line was obtained. The slope was used to calculate Caspase-1 activity.

Cathepsin K: Screening for Cathepsin K (EC 3.4.22.38) inhibitors was performed using the Cathepsin K Drug Discovery Kit $\left(\right.$ Enzo $^{\circledR}$ Life Sciences, Farmingdale, New York, USA) according to the manufacturer's guidelines. Cathep$\sin \mathrm{K}$ was pre-incubated for $30 \mathrm{~min}$ at $37{ }^{\circ} \mathrm{C}$ with either none, 100 or $200 \mathrm{nM}$ inhibitor protein.

Matrix-Metalloproteinase-P9 (MMP-9): Screening for MMP-9 (EC 3.4.24.35) inhibitors was performed using the MMP-9 colorimetric drug discovery kit $\left(\right.$ Enzo $^{\circledR}$ Life Sciences, Farmingdale, New York, USA) according to the manufacturer's guidelines. MMP-9 was pre-incubated for $30 \mathrm{~min}$, at $37^{\circ} \mathrm{C}$ with either none (control), 200 or $400 \mathrm{nM}$ inhibitor protein.

5-Lipoxygenase (5-Lox): Lipoxygenase (EC 1.13.11.34) activity was assayed using the Lipoxygenase Inhibitor Screening Assay Kit (Cayman Chemical Company, Ann Arbor, MI, USA) according to the manufactures guidelines. 5-Lipoxygenase from Solanum tuberosum (potato) was purchased from Cayman Chemical Company (Ann Arbor, MI, USA). Linolenic acid was used as substrate. Residual 5-Lox activity was determined after pre-incubation for 15 min at $4{ }^{\circ} \mathrm{C}$ with either none (control), 200 or $400 \mathrm{nM}$ protease inhibitor. Data analysis was performed according to the instructions supplied with the assay kit.

\section{Results}

Isolation of novel inhibitor variants from tuber cDNA libraries

In total 9,600 cDNA clones were randomly selected from small libraries prepared from mature tuber mRNA of ten potato genotypes (960 ESTs/cDNA library) and sequenced.
One-hundred and seventy-five mostly full length cDNA clones encoding various inhibitor types were identified based on sequence similarity to known inhibitors in the GenBank core collection. After the removal of duplicate sequences, 120 unique inhibitor sequences remained, which matched to 31 loci in the potato genome (Fig. 1, supplemental Table 1). The deduced polypeptide sequence of 88 inhibitors $(73 \%$ ) differed between $1 \%$ and $18 \%$ from inhibitor sequences present in the GenBank core collection. The nucleotide sequences fell into 19 structural groups with the largest group corresponding to Kunitz-type inhibitors A and B (supplemental Table 1). The Kunitztype protease inhibitor (KTI) family accounted for $52 \%$ of the inhibitor collection. The KTI family is divided into six structural groups (A, B, C, D, M and K) (Speranskaya et al. 2012), four of which were represented in the inhibitor collection (A, B, C and D). Fourteen KTIs assigned to group A (KTI-A), 33 in group B (KTI-B), 12 in group C (KTI-C) and 4 in group D (KTI-D) matched to two, one, three and two loci, respectively, in the potato genome (PGSC 2011) (supplemental Table 1, Fig. 1).The second largest group corresponded to the potato protease inhibitor (PIN) family. PINs are divided in two structural groups. Accordingly, 9 and 8 cDNAs were classified as members of the subfamilies PIN I and PIN II, respectively. The 17 PINs matched to three loci. Nine sequences were assigned to pectin methylesterase inhibitors (PMEI) derived from three loci. Seven cDNAs each were identified as metallocarboxypeptidase inhibitors and defensins or Gamma-thionins. The remaining 17 cDNAs were classified in other inhibitor families like BAX, RNase E and putative phosphatase 2A (PPA 2A) inhibitors.

Inhibitor heterologous expression and purification

Twenty-nine inhibitors were selected for functional characterization of fusion proteins expressed in Pichia pastoris (supplemental Figure 1). The majority of the inhibitors were chosen based on previously described pharmacological properties of representatives of the KTI and PIN families. The major KTI structural groups A, B and C were represented by seven, twelve and three inhibitor variants, respectively. The PIN family was represented by two inhibitors each of the PIN I and PIN II sub-family. In addition to the KTI and PIN representatives, one PMEI, one RNase $\mathrm{E}$ and the unique 'Cyclin dependent kinase inhibitor $2^{\prime}$ were selected. The sequences corresponding to the mature inhibitor polypeptides of 23 inhibitors (5 KTI-A, $10 \mathrm{KTI}-$ B, 3 KTI-C, 2 PIN I, 2 PIN II, 1 PMEI) were successfully expressed in Pichia pastoris. Expression of seven inhibitors could not be detected in the P. pastoris system. Fusion proteins were purified from the culture medium by affinity chromatography. As an example, purification of the KTI-C 
Potato tuber proteinaceous inhibitors
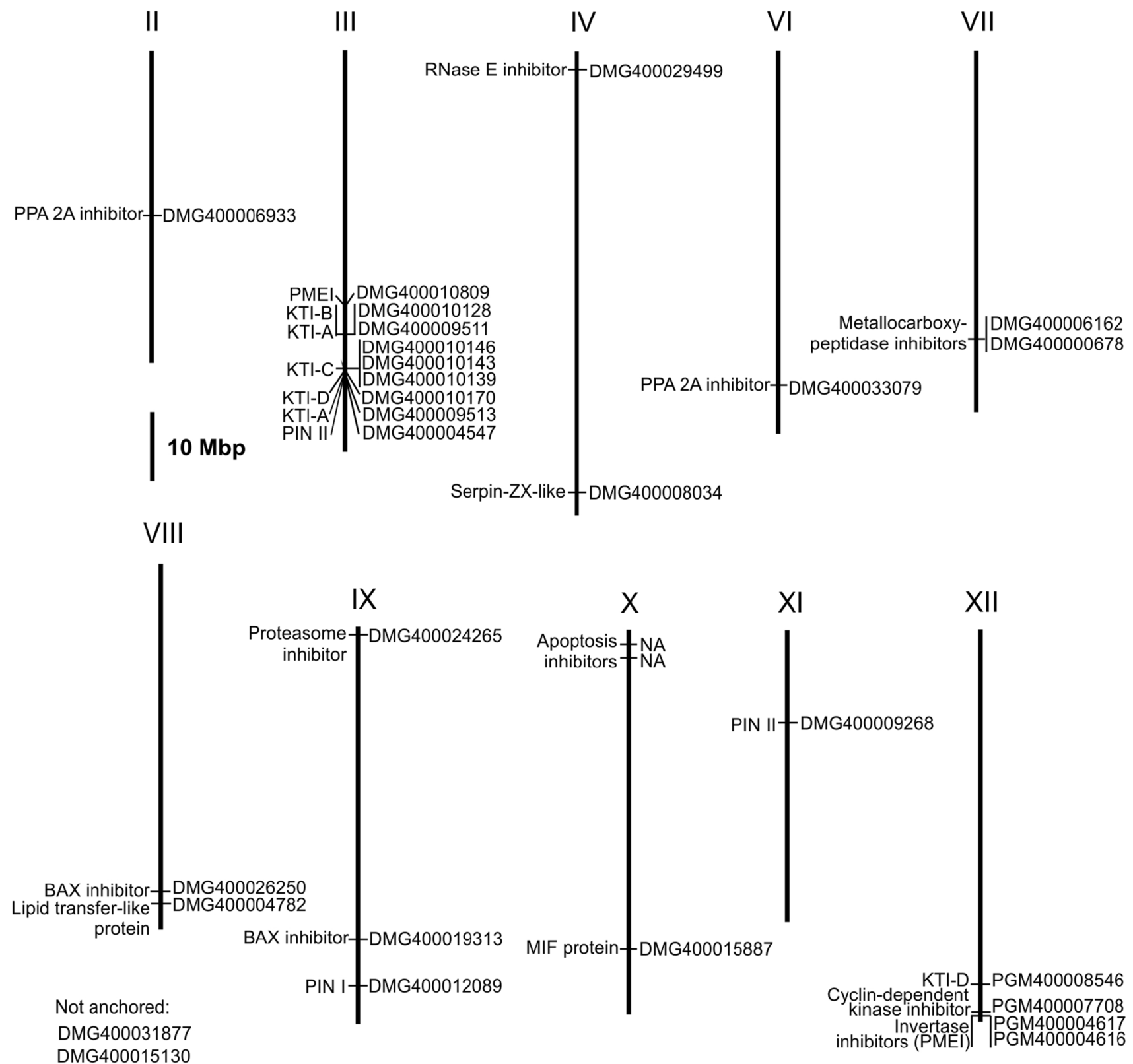

Fig. 1 Physical map of genes encoding potato proteinaceous enzyme inhibitors. Genomic positions are according to the potato pseudomolecules (version 4.03) at http://potato.plantbiology.msu.edu/cgibin/gbrowse/potato/. Locus identifiers are shown to the right and

inhibitor PI1410 is shown in Fig. 2. Following SDS-PAGE a faint band of $23 \mathrm{kDa}$ was visible in the P.pastoris growthmedia corresponding to the expected size of the fusion protein (Fig. 2a, Lane 1). Further purification by ammonium sulfate precipitation and affinity chromatography resulted in an enrichment of the $23 \mathrm{kDa}$ protein band (Fig. 2a, Lane names of encoded inhibitors are shown to the left of the chromosomes. Further details are shown in supplemental Table 1. NA: the locus is not annotated in the potato genome

3). The purified fusion protein was identified by Western blot analysis using a myc-tag antibody as probe (Fig. 2b, Lane 1). All 23 inhibitors were expressed in P. pastoris cells as described for PI1410 and expression was verified by Western blot analysis (data not shown). Inhibition assays were carried out using the purified inhibitor fusion protein. 


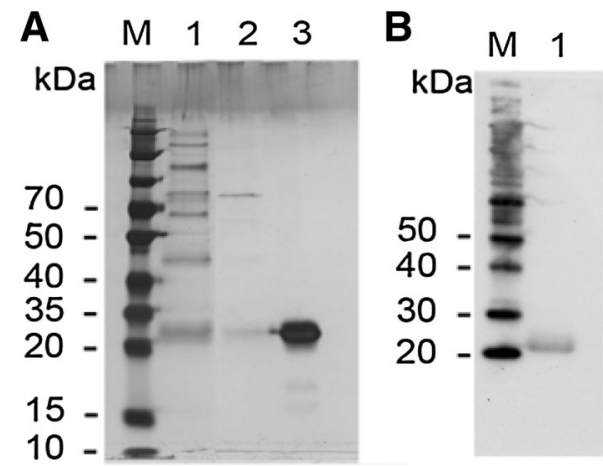

Fig. 2 Purification of the PI1410 fusion protein from P. pastoris culture media by affinity chromatography. a Coomassie stained SDSPAGE. Lane 1, P. pastoris culture media supernatant after $72 \mathrm{~h}$ induction of PI1410 expression by methanol. Lane 2, proteins precipitated with $40 \%$ Ammonium sulfate from $P$. pastoris culture media. Lane 3, purified and concentrated PI1410 inhibitor protein. b Western blot analysis. Lane 1, purified and concentrated PI1410 inhibitor protein following incubation with anti-myc-tag antibody. $M$ molecular weight standards

Protease and enzyme inhibition by recombinant inhibitor proteins

Purified inhibitor proteins were tested for in vitro inhibition of the serine proteases trypsin, elastase (pig pancreas, PPE, human leukocyte, HLE), dipeptidylpeptidase IV (DPP IV), factor IXa (FIXa), factor Xa (FXa) and thrombin. Four inhibitors (PI6033, PI0875, PI6362, PI0234) did not show any inhibitory activity on any of the enzymes tested (not shown). The serine proteases HLE, DPP IV, FIXa, FXa and thrombin, the cysteine proteases Calpain-1, Caspase-1 and the matrix-metallopeptidase-9 (MMP-9) were not affected by any of the tested inhibitors (not shown). Many inhibitors from the KTI, PIN and PMEI families are known to inhibit trypsin (Bauw et al. 2006; Heibges et al. 2003b; Jorgensen et al. 2006; Pouvreau et al. 2001). Trypsin inhibition among and within the inhibitor families was highly diverse, ranging from 0 to $87 \%$ inhibition (Table 2). Among the KTIs, trypsin was inhibited primarily by members of subgroup B and percent inhibition varied from $16 \%$ (PI8311) to $83 \%$ (PI5918) (Table 2). KTI-A and KTI-C inhibitors had no or minor inhibitory effects on trypsin. Three PINs showed inhibitory properties comparable to KTI-B proteins (Table 2). The representative of the PMEI family (PI7531) showed only mild trypsin inhibition (10 \%). Both PIN II inhibitors PI4434 and PI6669 inhibited the pig pancreas elastase with IC50 values of $0.67 \mu \mathrm{M}$ and $0.97 \mu \mathrm{M}$, respectively (Table 2). Furthermore, the fusion proteins were tested for inhibition of the aspartyl proteases $\beta$-secretase (BACE) and HIV-1 protease. Inhibitors related to KTI-B and KTI-C subfamilies were responsible for BACE inhibition when tested individually. The KTI-B inhibitors
PI8234, PI2112, PI5887 and PI4587 and the KTI-C inhibitor PI5446 strongly inhibited BACE with IC50 values between $0.36 \mu \mathrm{M}$ and $0.81 \mu \mathrm{M}$ (Table 2). HIV-1 protease was inhibited by the PIN I inhibitor PI6013 with an IC50 value of $0.67 \mu \mathrm{M}$ (Table 2). The cysteine protease Cathepsin K was effectively inhibited by all three KTI-Cs tested (PI410, PI5446, PI4202) and by the PIN I inhibitor PI6013, which in addition inhibited the HIV-1 protease (Table 2). The KTI-C inhibitors with IC50 values between 0.02 and $0.09 \mu \mathrm{M}$ were more effective than the PIN I inhibitor with an IC50 value of $0.77 \mu \mathrm{M}$. 5-Lipoxygenase was the only non-proteolytic enzyme tested. 5-Lipoxygenase was exclusively inhibited by all three KTI-C inhibitors PI1410, PI5446 and PI420 with IC50 values of $1.59 \mu \mathrm{M}, 1.01 \mu \mathrm{M}$ and $1.28 \mu \mathrm{M}$, respectively.

\section{Discussion}

Sequencing 9,600 randomly selected cDNA clones from mature potato tuber tissue of ten cultivars yielded 175 cDNA clones coding for various enzyme inhibitors according to sequence similarity. The overall transcript frequency of inhibitors was $1.8 \%$, which is in the same order of magnitude as previously observed in 1,600 cDNA clones from tubers of cultivars Provita and Saturna (Heibges et al. 2003a). The number of inhibitors isolated from individual cultivars varied widely, from three in cv Elfe to thirty-one in cv Solara, indicating large variation of inhibitor transcript levels, which could result from genotypic differences or different physiological states of the tubers used for library construction. Consistent with previous observations (Heibges et al. 2003a) the majority of all inhibitors slightly differed from sequences described in GenBank. The 120 unique nucleotide sequences matched to 31 loci on 10 of the 12 potato chromosomes. The number of coding loci could be smaller, as some inhibitors matched with similar high scores to more than one locus. This indicates that many sequence variants were allelic. In particular, the 59 KTI's in groups A, B and C originated from only six loci, confirming the large allelic diversity of these genes.

To test whether structural variation is accompanied by functional diversification, we selected 29 representatives of various inhibitor classes for heterologous expression in the yeast $P$. pastoris. Twenty-three inhibitors could be expressed in soluble form and purified in sufficient quantity, mostly KTI's and PIN's. The recombinant proteins were evaluated for in vitro enzyme inhibitory functions. Four purified, soluble inhibitor proteins (PI6033, PI0875, PI6362, PI0234) did not show any biological activity, neither against trypsin, the most commonly used enzyme for protease inhibition assays, nor any of the other enzymes tested. These proteins might have folded incorrectly or 
Table 2 In vitro inhibition of proteases and lipoxygenase by heterologous expressed potato tuber protease inhibitors

\begin{tabular}{|c|c|c|c|c|c|c|c|}
\hline Inhibitor type & Inhibitor ID & $\begin{array}{l}\text { Trypsin } \\
\text { EC3.4.21.4 }\end{array}$ & $\begin{array}{l}\text { Pig pan- } \\
\text { creas elastase } \\
\text { EC3.4.21.36 }\end{array}$ & $\begin{array}{l}\text { BACE }(\beta \text {-secretase }) \\
\text { EC3.4.23.46 }\end{array}$ & $\begin{array}{l}\text { Cathepsin K } \\
\text { EC3.4.22.38 }\end{array}$ & $\begin{array}{l}\text { 5-Lipoxygenase } \\
\text { EC1.13.11.34 }\end{array}$ & $\begin{array}{l}\text { HIV-1 protease } \\
\text { EC3.4.23.16 }\end{array}$ \\
\hline KTI-A & PI9070 & 9 & - & - & - & - & - \\
\hline KTI-A & PI4063 & 6 & - & - & - & - & - \\
\hline KTI-B & PI4435 & 62 & - & - & - & - & - \\
\hline KTI-B & PI4587 & 53 & - & $+(\mathrm{IC50} 0.81 \mu \mathrm{M})$ & - & - & - \\
\hline KTI-B & PI8234 & 59 & - & $+(\mathrm{IC} 500.4 \mu \mathrm{M})$ & - & - & - \\
\hline KTI-B & PI2112 & 65 & - & $+($ IC50 $0.36 \mu \mathrm{M})$ & - & - & - \\
\hline KTI-B & PI2568 & 55 & - & - & - & - & - \\
\hline KTI-B & PI5887 & 38 & - & $+(\operatorname{IC50} 0.47 \mu \mathrm{M})$ & - & - & - \\
\hline KTI-B & PI8383 & 61 & - & - & - & - & - \\
\hline KTI-B & PI5918 & 83 & - & - & - & - & - \\
\hline KTI-B & PI8311 & 16 & - & - & - & - & - \\
\hline KTI-B & PI9142 & 53 & - & - & - & - & - \\
\hline KTI-C & PI1410 & 0 & - & - & $+($ IC50 $0.09 \mu \mathrm{M})$ & $+($ IC50 $1.59 \mu \mathrm{M})$ & - \\
\hline KTI-C & PI5446 & 5 & - & $+($ IC50 $0.72 \mu \mathrm{M})$ & $+($ IC50 $0.08 \mu \mathrm{M})$ & $+($ IC50 $1.01 \mu \mathrm{M})$ & - \\
\hline KTI-C & PI4202 & 5 & - & - & $+($ IC50 $0.02 \mu \mathrm{M})$ & $+($ IC50 $1.28 \mu \mathrm{M})$ & - \\
\hline PIN I & PI6013 & 44 & - & - & $+($ IC50 $0.77 \mu \mathrm{M})$ & - & $\begin{array}{l}+(\text { IC } 50 \\
0.67 \mu \mathrm{M})\end{array}$ \\
\hline PIN II & PI4434 & 43 & $+(\mathrm{IC} 500.67 \mu \mathrm{M})$ & - & - & - & - \\
\hline PIN II & PI6669 & 87 & $+(\mathrm{IC50} 0.97 \mu \mathrm{M})$ & - & - & - & - \\
\hline PMEI & PI7531 & 10 & - & - & - & - & - \\
\hline
\end{tabular}

a Inhibition at a molar ratio 2:1 of inhibitor: trypsin

lacked components required for activity or their activity spectrum is completely different from the one covered in our study.

The remaining nineteen proteins inhibited with different efficiency trypsin, the pharmacological important proteases pig pancreatic elastase, human $\beta$-secretase (BACE1), human cathepsin K, and human HIV-1 protease, and potato 5-lipoxygenase. Trypsin and elastase are digestive proteases of insects that were previously shown to be targeted by plant PIs in the context of plant defense against herbivores (Hartl et al. 2011; Major and Constabel 2008; Turra et al. 2009). Among the tested KTI's trypsin was effectively inhibited only by group B inhibitors, whereas group A and C KTI's showed weak or no trypsin inhibition. This contrasts a previous study (Heibges et al. 2003b) where both A and B KTIs inhibited trypsin when the fusion proteins were expressed in the fission yeast $S$. pombe. The discrepancies may be the consequence of the different heterologous expression systems and tags used. The KTI-A inhibitor constructs expressed in P. pastoris might have been non-functional due to incorrect protein folding or lack of disulfide bridge formation. In addition to trypsin, four of ten biologically active KTI-B proteins inhibited BACE1 , demonstrating functional diversity within this group of allelic sequences. In agreement with previous functional studies (Glaczinski et al. 2002; Heibges et al. 2003b) trypsin inhibition by KTI's in group C was low or even absent, which is likely due to a different substrate specificity. The three KTI's in group $\mathrm{C}$ were biologically active since they all inhibited cathepsin $\mathrm{K}$ and potato 5-lipoxygenase. In addition, the KTI-C inhibitor PI5446 showed inhibitory properties on BACE-1. This functional difference presumably reflects the sequence diversity within the KTI-C family. The KTI group C proteins inhibited most effectively the cysteine protease cathepsin $\mathrm{K}$, suggesting cysteine proteases as their main targets, although they show no homology to known cysteine protease inhibitor superfamilies (Bevec et al. 1996; Turk and Bode 1991). Further functions beyond protease inhibition are possible. Besides the newly identified inhibition of potato 5-lipoxygenase, KTI group C proteins have been found to inhibit in vitro soluble potato tuber invertase. KTI-C inhibitor PI4202 is identical to these putative invertase inhibitors characterized previously (Glaczinski et al. 2002).

Besides the serine protease trypsin, the potato proteinase inhibitor I (PIN I) PI6013 inhibited the cysteine protease cathepsin K and the aspartyl protease HIV-1. This PIN I protein seems to have multiple specificities. Previous studies had revealed high inter- and intra-specific structural and functional diversity among the PIN I family (Jorgensen 
et al. 2011; Turra et al. 2009). Native PIN I proteins have been suggested to occur as hexameric protein complexes in which every monomer represents a functional unit (van den Broek et al. 2004). PIN I monomers interact with the reactive center of a protease by a constrained loop protruding from the surface of the molecule (Mcphalen and James 1988; Mcphalen et al. 1985). Substrate specificity is supposed to be determined by the amino acid composition of the reactive loop. A lysine residue may interact with trypsin-like proteases while leucine or methionine at the same position in the reactive loop will bind to and inhibit proteases specific for hydrophobic side chains such as chymotrypsin (Jorgensen et al. 2011; van den Broek et al. 2004). PI6013 possesses an alanine residue at the corresponding position in the reactive loop, which might explain the different substrate specificities of this inhibitor.

Two representatives from the potato proteinase inhibitor family II (PIN II) inhibited trypsin and in addition elastase from pig pancreas (PPE). The activity of human leukocyte elastase was not affected. Members of the PIN II family are mainly found in the Solanaceae. Initially characterized in potato tubers they have been detected in leaves, flowers, fruits and phloem tissue of different Solanaceous species (Christeller and Laing 2005; Iwasaki et al. 1971; Miller et al. 2000; Pearce et al. 1993, 1988). Interestingly, PPE has been used as model system in several pharmacological screening assays for finding human leucocyte elastase (HLE) inhibitors. PIN II proteins function in planta presumably in defense reactions in response to the attack of herbivores and other pests (Hartl et al. 2010). The PIN II proteins PI4434 and PI6669 may act on insect gut proteases as part of constitutive defense mechanisms against herbivores in potato tubers and other tissues.

Diversity and abundance of plant protease inhibitors make them excellent sources for discovering novel enzyme inhibitors with specific pharmacological effects. Previous studies revealed several plant proteinase inhibitors acting on proteases involved in blood coagulation, fibrinolysis, inflammation or tumor cell proliferation [reviewed in (Oliva and Sampaio 2009) and (Fear et al. 2007)]. The therapeutic effect of a soybean derived Bowman-Birk inhibitor (BBI) in inflammatory diseases and cancer has been shown in several completed or ongoing human trials (Safavi and Rostami 2012). To the best of our knowledge, this is the first report of plant-derived Kunitz-type inhibitors with inhibitory activity on BACE- 1 and cathepsin K, and a PIN I protein restricting HIV-1 protease activity. Human BACE-1 catalyzes the initial step in amyloidogenic metabolism of the large transmembrane amyloid precursor protein (APP) leading to the release of the amyloid $\beta$-peptide $(A \beta)$ (Sinha and Lieberburg 1999). A $\beta$ was identified as the main constituent of extracellular plaques in human brain which are characteristic for Alzheimer's disease (Glenner and Wong
1984; Masters et al. 1985). Inhibition of BACE-1 could potentially reduce the extent of amyloid plaques and slow down or reverse the progression of the disease. Hence, the design of selective inhibitors of BACE-1 has been the target of intensive pharmaceutical development (Ghosh et al. 2008). Clinical effective BACE-1 inhibitors require high specificity and the ability to penetrate the blood-brain barrier and neuronal membranes. The KTI-B inhibitors of BACE-1 in our set exhibited higher substrate specificity compared to the KTI-C inhibitor, which qualifies them as lead structures for further research on drug development. The tested KTI-C inhibitors (PI5446, PI1410 and PI4202) were the most effective inhibitors of cathepsin $\mathrm{K}$ in our experiments. Cathepsin $\mathrm{K}$ is a lysosomal cysteine protease involved in osteoclast-mediated bone resorption. Inhibition of cathepsin $\mathrm{K}$ represents a potentially effective therapeutic approach for treating diseases characterized by excessive bone resorption, such as osteoporosis. KTI-C inhibitors showed a broader range of biological activity than KTI-B inhibitors, since members of this group inhibited 5-lipoxygenase in addition to BACE-1 and Cathepsin K. Nevertheless, the KTI-C inhibitors present potent starting points for protein engineering with the aim to increase substrate specificity. The same is true for the PINI inhibitor PI6013, which showed similar inhibitory properties on cathepsin K as well as HIV-protease, which is involved in virus proliferation (Sundquist and Kräusslich 2012).

The biological activity of potato KTIs is not limited to protease inhibition. Besides inhibition of invertase by specific members of the KTI-C family (Glaczinski et al. 2002), we demonstrated in this study that three KTI-C recombinant proteins inhibit potato 5-lipoxygenase. Plant lipoxygenases (LOX) are key enzymes in the biosynthesis of oxylipins, which play important roles in plant defense and development (Feussner and Wasternack 2002). The substrates of LOX are polyunsaturated fatty acids. The 5-LOX activity converts arachidonic acid in 5-Hydroperoxyeicosatetraenoic acid (5-HPETE), an intermediate in the biosynthesis of leukotrienes and other eicosanoids. The 5-LOX pathway is not only relevant for plant defense (Bostock et al. 1992) but also for inflammatory processes in humans leading to pathologies such as asthma and allergic reactions (Harizi and Gualde 2004). 5-LOX inhibitors have, therefore, been the targets of drug development (Williams and Spector 2009). The inhibition of LOX also opens up new possibilities for the in planta function of KTIs beyond protease inhibition. The new inhibitory functions discovered in this study might be just the tip of an iceberg, as our functional screens covered only a small fraction of enzymatic reactions. Screening recombinant potato inhibitors on additional classes of enzymes might reveal further biological activities.

In conclusion, we provide novel insights into the structural and functional diversity of proteinaceous inhibitors 
of potato tubers, which have potential for biotechnological applications. We identified inhibitors for proteases involved in severe human diseases, which may be used in drug development. Further studies of the mechanism of action and binding of natural inhibitors can provide leads for developing therapeutic agents against human diseases. The discovery of LOX inhibition by certain Kunitz-type inhibitors opens new possibilities for the in vivo functional role of this abundant class of tuber proteins.

Acknowledgments This research was carried out in the department Plant Breeding and Genetics headed by Maarten Koornneef. Funding was provided by the Max-Planck Society within the BIOSOL project (molecular analysis and sustainable utilization of BIOdiversity of SOLanum tuberosum), in cooperation with the Fraunhofer Society.

Open Access This article is distributed under the terms of the Creative Commons Attribution License which permits any use, distribution, and reproduction in any medium, provided the original author(s) and the source are credited.

\section{References}

Balls AK, Ryan CA (1963) Concerning a crystalline chymotryptic inhibitor from potatoes, and its binding capacity for enzyme. J Biol Chem 238:2976-2982

Bateman KS, James MN (2011) Plant protein proteinase inhibitors: structure and mechanism of inhibition. Curr Protein Pept Sci 12:340-347

Bauw G, Nielsen HV, Emmersen J, Nielsen KL, Jorgensen M, Welinder KG (2006) Patatins, Kunitz protease inhibitors and other major proteins in tuber of potato cv. Kuras. Febs J 273:3569-3584

Bevec T, Stoka V, Pungercic G, Dolenc I, Turk V (1996) Major histocompatibility complex class II-associated p41 invariant chain fragment is a strong inhibitor of lysosomal cathepsin L. J Exp Med 183:1331-1338

Bostock RM, Yamamoto H, Choi D, Ricker KE, Ward BL (1992) Rapid stimulation of 5-lipoxygenase activity in potato by the fungal elicitor arachidonic acid. Plant Physiol 100:1448-1456

Chen MS (2008) Inducible direct plant defense against insect herbivores: a review. Insect Sci 15:101-114

Christeller J, Laing W (2005) Plant serine proteinase inhibitors. Protein Peptide Lett 12:439-447

Cruz-Silva I, Gozzo AJ, Nunes VA, Carmona AK, Faljoni-Alario A, Oliva ML, Sampaio MU, Sampaio CA, Araujo MS (2004) A proteinase inhibitor from Caesalpinia echinata (pau-brasil) seeds for plasma kallikrein, plasmin and factor XIIa. Biol Chem 385:1083-1086

De Leo F, Volpicella M, Licciulli F, Liuni S, Gallerani R, Ceci LR (2002) PLANT-PIs: a database for plant protease inhibitors and their genes. Nucleic Acids Res 30:347-348

Dunse KM, Stevens JA, Lay FT, Gaspar YM, Heath RL, Anderson MA (2010) Coexpression of potato type I and II proteinase inhibitors gives cotton plants protection against insect damage in the field. Proc Natl Acad Sci USA 107:15011-15015

Fear G, Komarnytsky S, Raskin I (2007) Protease inhibitors and their peptidomimetic derivatives as potential drugs. Pharmacol Therapeut 113:354-368

Feussner I, Wasternack C (2002) The lipoxygenase pathway. Annu Rev Plant Biol 53:275-297
Ghosh AK, Gemma S, Tang J (2008) beta-Secretase as a therapeutic target for Alzheimer's disease. Neurotherapeutics 5:399-408

Glaczinski H, Heibges A, Salamini R, Gebhardt C (2002) Members of the Kunitz-type protease inhibitor gene family of potato inhibit soluble tuber invertase in vitro. Potato Res 45:163-176

Glenner GG, Wong CW (1984) Alzheimers-disease-initial report of the purification and characterization of a novel cerebrovascular amyloid protein. Biochem Bioph Res Co 120:885-890

Harizi H, Gualde N (2004) 5-Lipoxygenase pathway, dendritic cells, and adaptive immunity. J Biomed Biotechnol 2:99-105

Hartl M, Giri AP, Kaur H, Baldwin IT (2010) Serine protease inhibitors specifically defend Solanum nigrum against generalist herbivores but do not influence plant growth and development. Plant Cell 22:4158-4175

Hartl M, Giri AP, Kaur H, Baldwin IT (2011) The multiple functions of plant serine protease inhibitors: defense against herbivores and beyond. Plant Signal Behav 6:1009-1011

Heibges A, Glaczinski H, Ballvora A, Salamini F, Gebhardt C (2003a) Structural diversity and organization of three gene families for Kunitz-type enzyme inhibitors from potato tubers (Solanum tuberosum L.). Mol Genet Genomics 269:526-534

Heibges A, Salamini F, Gebhardt C (2003b) Functional comparison of homologous members of three groups of Kunitz-type enzyme inhibitors from potato tubers (Solanum tuberosum L.). Mol Genet Genomics 269:535-541

Ishikawa A, Ohta S, Matsuoka K, Hattori T, Nakamura K (1994) A family of potato genes that encode Kunitz-type proteinase-inhibitors - structural comparisons and differential expression. Plant Cell Physiol 35:303-312

Iwasaki T, Kiyohara T, Yoshikawa M (1971) Purification and partial characterization of two different types of proteinase inhibitors (inhibitors II-a and II-b) from potatoes. J Biochem 70:817-826

Johnson R, Ryan CA (1990) Wound-inducible potato inhibitor-II genes - enhancement of expression by sucrose. Plant Mol Biol 14:527-536

Jongsma MA, Bolter C (1997) The adaptation of insects to plant protease inhibitors. J Insect Physiol 43:885-895

Jorgensen M, Bauw G, Welinder KG (2006) Molecular properties and activities of tuber proteins from starch potato cv. Kuras. J Agr Food Chem 54:9389-9397

Jorgensen M, Stensballe A, Welinder KG (2011) Extensive post-translational processing of potato tuber storage proteins and vacuolar targeting. FEBS J 278:4070-4087

Major IT, Constabel CP (2008) Functional analysis of the Kunitz trypsin inhibitor family in poplar reveals biochemical diversity and multiplicity in defense against herbivores. Plant Physiol 146:888-903

Masters CL, Simms G, Weinman NA, Multhaup G, Mcdonald BL, Beyreuther K (1985) Amyloid plaque core protein in Alzheimer-disease and down syndrome. Proc Natl Acad Sci USA 82:4245-4249

Mcphalen CA, James MNG (1988) Structural comparison of 2 serine proteinase protein inhibitor complexes - Eglin-C-subtilisin Carlsberg and Ci-2-subtilisin Novo. Biochemistry 27:6582-6598

Mcphalen CA, Svendsen I, Jonassen I, James MNG (1985) Crystal and molecular structure of chymotrypsin inhibitor-2 from barley seeds in complex with subtilisin Novo. Proc Natl Acad Sci USA 82:7242-7246

Miller EA, Lee MCS, Atkinson AHO, Anderson MA (2000) Identification of a novel four-domain member of the proteinase inhibitor II family from the stigmas of Nicotiana alata. Plant Mol Biol 42:329-333

Mosolov VV, Valueva TA (2005) Proteinase inhibitors and their function in plants: a review. Appl Biochem Microbiol 41:227-246

Nakahata AM, Bueno NR, Rocha HAO, Franco CRC, Chammas R, Nakaie CR, Jasiulionis MG, Nader HB, Santana LA, Sampaio 
MU, Oliva MLV (2006) Structural and inhibitory properties of a plant proteinase inhibitor containing the RGD motif. Int J Biol Macromol 40:22-29

Neuhof C, Oliva ML, Maybauer D, Maybauer M, de Oliveira C, Sampaio MU, Sampaio CA, Neuhof H (2003) Effect of plant Kunitz inhibitors from Bauhinia bauhinioides and Bauhinia rufa on pulmonary edema caused by activated neutrophils. Biol Chem 384:939-944

Odeny DA, Stich B, Gebhardt C (2010) Physical organization of mixed protease inhibitor gene clusters, coordinated expression and association with resistance to late blight at the StKI locus on potato chromosome III. Plant Cell Environ 33:2149-2161

Oliva ML, Sampaio UM (2008) Bauhinia Kunitz-type proteinase inhibitors: structural characteristics and biological properties. Biol Chem 389:1007-1013

Oliva MLV, Sampaio MU (2009) Action of plant proteinase inhibitors on enzymes of physiopathological importance. An Acad Bras Cienc 81:615-621

Oliva ML, Souza-Pinto JC, Batista IF, Araujo MS, Silveira VF, Auerswald EA, Mentele R, Eckerskorn C, Sampaio MU, Sampaio CA (2000) Leucaena leucocephala serine proteinase inhibitor: primary structure and action on blood coagulation, kinin release and rat paw edema. Biochim Biophys Acta 1477:64-74

Oliva MLV, Silva MCC, Sallai RC, Brito MV, Sampaio MU (2010) A novel subclassification for Kunitz proteinase inhibitors from leguminous seeds. Biochimie 92:1667-1673

Oliveira C, Navarro-Xavier RA, Anjos-Vallota EA, Martins JO, Silveira VL, Goncalves LR, Araujo MS, Motta G, Sannomiya P, Oliva ML (2010) Effect of plant neutrophil elastase inhibitor on leucocyte migration, adhesion and cytokine release in inflammatory conditions. Br J Pharmacol 161:899-910

Pearce G, Ryan CA, Liljegren D (1988) Proteinase inhibitor-I and inhibitor-II in fruit of wild tomato species-transient components of a mechanism for defense and seed dispersal. Planta 175:527-531

Pearce G, Johnson S, Ryan CA (1993) Purification and characterization from tobacco (Nicotiana-tabacum) leaves of 6 small, woundinducible, proteinase iso inhibitors of the potato inhibitor-II family. Plant Physiol 102:639-644

PGSC (2011) Genome sequence and analysis of the tuber crop potato. Nature 475:189-195

Pouvreau L, Gruppen H, Piersma SR, van den Broek LAM, van Koningsveld GA, Voragen AGJ (2001) Relative abundance and inhibitory distribution of protease inhibitors in potato juice from cv Elkana. J Agr Food Chem 49:2864-2874

Rawlings ND, Morton FR, Kok CY, Kong J, Barrett AJ (2008) MEROPS: the peptidase database. Nucleic Acids Res 36:D320-D325

Ryan CA (1990) Protease inhibitors in plants—genes for improving defenses against insects and pathogens. Annu Rev Phytopathol 28:425-449

Safavi F, Rostami A (2012) Role of serine proteases in inflammation: bowman-Birk protease inhibitor (BBI) as a potential therapy for autoimmune diseases. Exp Mol Pathol 93:428-433

Sinha S, Lieberburg I (1999) Cellular mechanisms of beta-amyloid production and secretion. Proc Natl Acad Sci USA 96:11049-11053

Speranskaya AS, Krinitsina AA, Kudryavtseva AV, Poltronieri P, Santino A, Oparina NY, Dmitriev AA, Belenikin MS, Guseva MA, Shevelev AB (2012) Impact of recombination on polymorphism of genes encoding Kunitz-type protease inhibitors in the genus Solanum. Biochimie 94:1687-1696

Sundquist WI, Kräusslich H-G (2012) HIV-1 Assembly, Budding, and Maturation. Cold Spring Harbor Perspectives in Medicine 2

Turk V, Bode W (1991) The cystatins - protein inhibitors of cysteine proteinases. FEBS Lett 285:213-219

Turra D, Bellin D, Lorito M, Gebhardt C (2009) Genotype-dependent expression of specific members of potato protease inhibitor gene families in different tissues and in response to wounding and nematode infection. J Plant Physiol 166:762-774

Valueva TA, Revina TA, Gvozdeva EL, Gerasimova NG, Ozeretskovskaya OL (2003) Role of protease inhibitors in potato protection. Russ J Bioorg Chem 29:454-458

van den Broek LAM, Pouvreau L, Lommerse G, Schipper B, van Koningsveld GA, Gruppen H (2004) Structural characterization of potato protease inhibitor I (cv. Bintje) after expression in Pichia pastoris. J Agr Food Chem 52:4928-4934

Williams FMK, Spector TD (2009) A new 5-lipoxygenase inhibitor seems to be safe and effective for the treatment of osteoarthritis. Nat Clin Pract Rheum 5:132-133

Zhu YC, Liu X, Maddur AA, Oppert B, Chen MS (2005) Cloning and characterization of chymotrypsin- and trypsin-like cDNAs from the gut of the Hessian fly [Mayetiola destructor (say)]. Insect Bioch Molec Biol 35:23-32 